\title{
Correction to: CONECT-6: a case-finding tool to identify patients with complex health needs
}

Catherine Hudon ${ }^{1 *}$, Mathieu Bisson ${ }^{1}$, Marie-France Dubois ${ }^{1}$, Yohann Chiu' ${ }^{1}$ Maud-Christine Chouinard², Nicole Dubuc ${ }^{1}$, Nicolas Elazhary ${ }^{1}$, Véronique Sabourin ${ }^{3}$ and Alain Vanasse ${ }^{1}$

\section{Correction to: BMC Health Serv Res 21, 157 (2021)} https://doi.org/10.1186/s12913-021-06154-4

Following publication of the original article [1], the authors would like to make some changes.

1. The percentage of participants in the Results under the Abstract section needs to be corrected.

The sentence currently reads:

The positive and negative predictive values were 49 and $75 \%$ respectively.

The sentence should read:

The positive and negative predictive values were 49 and $95 \%$ respectively.
2. The AUC has disappeared from Figure 2 (ROC curve) due to a typesetting mistake. The correct Figure 2 is shown below:

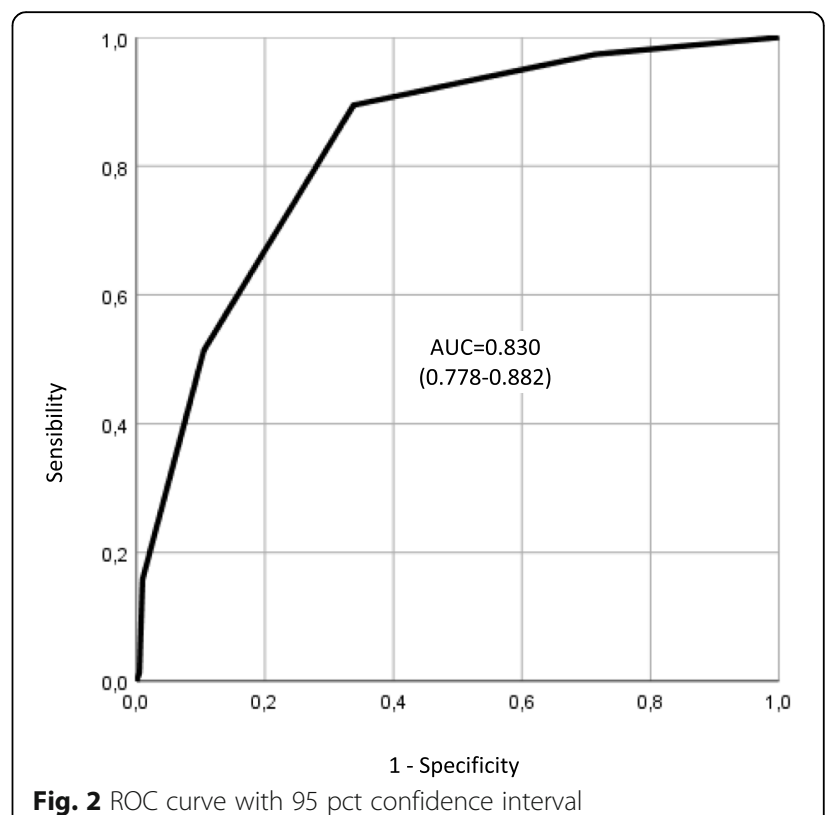

The original article can be found online at https://doi.org/10.1186/s12913021-06154-4.

* Correspondence: Catherine.Hudon@usherbrooke.ca

'Department of Family Medicine and Emergency Medicine, University of Sherbrooke, 3001 12e Avenue N, Sherbrooke, QC J1H 5H3, Canada

Full list of author information is available at the end of the article

C C The Author(s). 2021 Open Access This article is licensed under a Creative Commons Attribution 4.0 International License, which permits use, sharing, adaptation, distribution and reproduction in any medium or format, as long as you give appropriate credit to the original author(s) and the source, provide a link to the Creative Commons licence, and indicate if changes were made. The images or other third party material in this article are included in the article's Creative Commons licence, unless indicated otherwise in a credit line to the material. If material is not included in the article's Creative Commons licence and your intended use is not permitted by statutory regulation or exceeds the permitted use, you will need to obtain permission directly from the copyright holder. To view a copy of this licence, visit http://creativecommons.org/licenses/by/4.0/ The Creative Commons Public Domain Dedication waiver (http://creativecommons.org/publicdomain/zero/1.0/) applies to the data made available in this article, unless otherwise stated in a credit line to the data. 
3. There are currently two affiliations associated to Catherine Hudon, which are actually a duplicate (with a minor difference in the address). The author affiliation 2 needs to be removed, so that the correct authors affiliations are presented as below:

Catherine Hudon1*, Mathieu Bisson1, Marie-France Dubois1, Yohann Chiu1, Maud-Christine Chouinard2, Nicole Dubuc1, Nicolas Elazhary1, Véronique Sabourin3, Alain Vanasse1

1. Department of Family Medicine and Emergency Medicine, University of Sherbrooke, 3001 12e Avenue N, Sherbrooke, QC, Canada, J1H 5H3.

2. Nursing Faculty, University of Montreal, Pavillon Marguerite-d'Youville, C.P. 6128 succ. Centre-ville, Montréal, QC, Canada, H3C 3J7.

3. Integrated University Health and Social Services Centre of Saguenay-Lac-Saint-Jean, 225 rue Saint-Vallier, Chicoutimi, Quebec, G7H 5H6

The original article has been corrected.

\section{Author details}

'Department of Family Medicine and Emergency Medicine, University of Sherbrooke, 3001 12e Avenue N, Sherbrooke, QC J1H 5H3, Canada. ${ }^{2}$ Nursing Faculty, University of Montreal, Pavillon Marguerite-d'Youville, C.P. 6128 succ. Centre-ville, Montréal, OC H3C 3J7, Canada. ${ }^{3}$ Integrated University Health and Social Services Centre of Saguenay-Lac-Saint-Jean, 930 rue Jacques-Cartier E, Chicoutimi, QC G7H 7K9, Canada.

Published online: 09 April 2021

\section{Reference}

1. Hudon C, et al. CONECT-6: a case-finding tool to identify patients with complex health needs. BMC Health Serv Res. 2021;21:157. https://doi.org/1 0.1186/s12913-021-06154-4. 